\title{
Penetrating head trauma injury with an excellent outcome
}

\author{
Rui Ramos, ${ }^{1}$ Cristiano Antunes, ${ }^{1}$ Maria João Machado, ${ }^{1}$ Rui Almeida ${ }^{2}$
}

'Department of Neurosurgery, Hospital de Braga, Braga, Portugal

${ }^{2}$ Department of Neurosurgery, Hospital de Braga, Pituitary Tumours Group, Braga, Portugal

\section{Correspondence to}

Dr Rui Ramos,

ruimramos@hotmail.com

Accepted 5 May 2017

\section{DESCRIPTION}

A 55-year-old man was found at his workplace with a metal drill penetrating the midline of the posterior region of the sagittal suture. His Glasgow Coma Scale (GCS) was initially 9, but his condition deteriorated and required endotracheal intubation. CT of the brain showed that the drill had taken an intracranial course, from the transition of the middle to the posterior third of the superior sagittal sinus, crossing the right parietal and temporal lobes, and ending in contact with the tentorial surface of the cerebellum (figures 1 and 2). He underwent emergency surgery to remove the drill. The operation revealed complete destruction of the superior sagittal sinus. We performed emergent ligation but were unable to reconstruct the superior sagittal sinus because of profuse bleeding. At the follow-up visit 2 months after the surgery, we performed a CT venography, showing absence of flow in the middle and posterior thirds of the superior sagittal sinus (figure 3). His GCS was 15, with no motor neurological deficits and only minimal memory loss-a remarkably favourable outcome.

Laceration of the middle and posterior thirds of the superior sagittal sinus must always be repaired ${ }^{1}$ to preserve sinus blood flow. Its ligation or acute blockage is associated with bilateral venous infarcts,

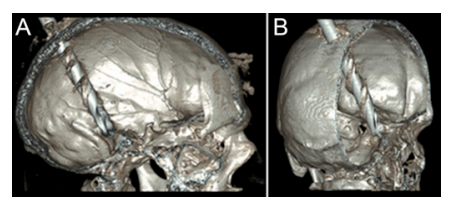

Figure 1 Preoperative brain CT, three-dimensional reconstruction, showing the drill entering the skull in the midline and ending in contact with the skull base. (A) Sagittal image. (B) Coronal image.

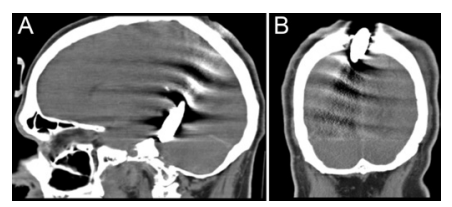

Figure 2 Preoperative brain CT showing the intracranial course of the drill, from the transition of the middle to the posterior third of the superior sagittal sinus, crossing the right parietal and temporal lobes, and ending in contact with the tentorial surface of the cerebellum. (A) Sagittal image. (B) Coronal image.

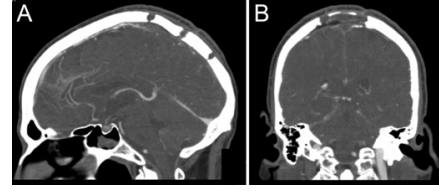

Figure 3 Cerebral CT venography, 2 months after the surgery, showing the craniotomy flap and absence of flow in the middle and posterior thirds of the superior sagittal sinus, with correct flow in the remaining venous sinus and deep venous system. (A) Sagittal image. (B) Coronal image.

as has been clinically and experimentally demonstrated. ${ }^{2}$ The anterior third is the only portion in which ligation is associated with questionable safety. ${ }^{2}$ In extreme cases, however, as in this report, with total destruction of the sinus causing uncontrollable haemorrhage, ligation of the middle and posterior thirds is not necessarily associated with a poor prognosis.

\section{Learning points}

- In extreme cases of total sinus destruction and massive bleeding, it may be necessary to ligate the middle and posterior thirds of the superior sagittal sinus.

- Ligation of the middle and posterior thirds of the superior sagittal sinus is not always associated with a poor prognosis.

Contributors RR: discussed planning, conduct, acquisition of data; drafted the article; revised the content, and finally approved the version. CA: drafted the article, revised the content and finally approved the version. MJM: drafted the article, revised the conten and finally approved the version. RA: discussed planning, drafted the article, revised the content and finally approved the version.

Competing interests None declared.

Patient consent Obtained.

Provenance and peer review Not commissioned; externally peer reviewed.

(C) BMJ Publishing Group Ltd (unless otherwise stated in the text of the article) 2017. All rights reserved. No commercial use is permitted unless otherwise expressly granted.

\section{REFERENCES}

1 Behera SK, Senapati SB, Mishra SS, et al. Management of superior sagittal sinus injury encountered in traumatic head injury patients: analysis of 15 cases. Asian J Neurosurg 2015;10:17-20.

2 Salunke P, Sodhi HB, Aggarwal A, et al. Is ligation and division of anterior third of superior sagittal sinus really safe? Clin Neurol Neurosurg 2013;115:1998-2002. 
Copyright 2017 BMJ Publishing Group. All rights reserved. For permission to reuse any of this content visit http://group.bmj.com/group/rights-licensing/permissions.

BMJ Case Report Fellows may re-use this article for personal use and teaching without any further permission.

Become a Fellow of BMJ Case Reports today and you can:

- Submit as many cases as you like

- Enjoy fast sympathetic peer review and rapid publication of accepted articles

Access all the published articles

- Re-use any of the published material for personal use and teaching without further permission

For information on Institutional Fellowships contact consortiasales@bmjgroup.com

Visit casereports.bmj.com for more articles like this and to become a Fellow 